\title{
Farklı Formlardaki Ginkgo biloba'nın Antioksidan Özelliklerinin Belirlenmesi
}

\author{
Önder Aybastier ${ }^{1 *}$ \\ ${ }^{1}$ Bursa Uludağ Üniversitesi, Fen Edebiyat Fakültesi, Kimya Bölümü, Bursa, Türkiye (ORCID: 0000-0002-0380-1992)
}

(Illk Geliş Tarihi 27 Ocak 2020 ve Kabul Tarihi 22 Şubat 2020)

(DOI: 10.31590/ejosat.680343)

ATIF/REFERENCE: Aybastıer, Ö. (2020). Farklı Formlardaki Ginkgo biloba'nın Antioksidan Özelliklerinin Belirlenmesi. Avrupa Bilim ve Teknoloji Dergisi, (18), 206-212.

$\ddot{O} \mathbf{z}$

Ginkgo biloba hem geleneksel hem de modern tıpta kullanılan ticari olarak önemli bir bitkidir. Dünyada ve ülkemizde ilaç, gıda takviyesi ve yaprak olmak üzere 3 farklı formda satışa sunulmaktadır. Bu çalışmada her 3 formdaki numunenin asitli ve asitsiz ortamda ultrasonik ekstraksiyonu gerçekleştirilerek antioksidan özellikleri incelenmiştir. Ekstraktların antioksidan kapasitesi ve toplam fenolik madde içeriği sırasıyla ABTS ve Folin-Ciocalteu yöntemleri ile incelenmiştir. Ayrıca HPLC (yüksek performanslı sıvı kromatografi) analizleri de yapılarak içerdikleri antioksidan maddeler tespit edilmiştir. Ginkgo biloba bitkisinin en yüksek miktarda içerdiği antioksidan maddenin bir flavonoid glikozit olan rutin olduğu belirlenmiştir. Çalışmanın sonucunda, ilaç formundaki ürünün gıda takviyesi ve yaprak formundaki ürünlerden daha iyi antioksidan özelliklere sahip olduğu ortaya konulmuştur.

\section{Determination of Antioxidant Properties of Ginkgo biloba in Different Forms}

\begin{abstract}
Ginkgo biloba is a commercially an important plant used in both traditional and modern medicine. It is offered for sale in 3 different forms as drug, food supplement and leaf in in the world and our country. In this study, antioxidant properties were investigated by extracting sample in all 3 forms in acidic and acid-free environment. The total antioxidant capacity and total phenolic content of extracts were investigated by ABTS and Folin-Ciocalteu methods, respectively. In addition, the antioxidant substances were determined by HPLC (high performance liquid chromatography) analysis. It was determined that the antioxidant substance that Ginkgo biloba plant contains in the highest amount is rutin, which is a flavonoid glycoside. As a result of the study, it has been demonstrated that the product in drug form has better antioxidant properties than products in food supplement and leaf form.
\end{abstract}

Keywords: Antioxidant, Ginkgo biloba, food supplement, HPLC

\footnotetext{
* Sorumlu Yazar: Bursa Uludağ Üniversitesi, Fen-Edebiyat Fakültesi, Kimya Bölümü, Bursa, Türkiye, ORCID: 0000-0002-0380-1992, aybastier@uludag.edu.tr
} 


\section{Giriş}

Ginkgo biloba (mabet ağacı) 1000-3000 yıl arasında yaşayabilen çok uzun ömürlü bir ağaçtır (Hohmann ve ark., 2018). Boyu 30 40 m'yi bulabilmektedir. Ginkgo biloba yaklaşık 200 milyon yıldır yeryüzünde yaşayan en eski ağaç türüdür. Ginkgo biloba yaprakları ve tohumlarının tedavi amaçlı kullanımından ilk kez 5000 yıl önce Çin kaynaklarında bahsedilmiştir (Rouse, 1998). Günümüzde Asya, Avrupa ve Kuzey Amerika'da Ginkgo biloba ağaçları bulunmaktadır (Nakanishi, 2005). Çin'de yüzyıllar boyu Ginkgo biloba yapraklarının nörolojik rahatsızlıklarda yararlı olduğuna inanılmış ve kullanılmıştır. Yapılan çalışmalar sonucunda antioksidan ve antiinflamatuar etkisinin olduğu gösterilmiştir. Geleneksel Çin tedavi sisteminde, bitkinin meyveleri kullanılmasına karşın, Amerika ve Avrupa ülkelerinde yaprak ekstreleri kullanılmaktadır (Liu ve ark., 2018; Pohl ve Lin, 2018).

Ginkgo biloba yaprakları, terpenoidler, flavonoidler, biflavonoidler, organik asitler, fenolikler gibi bileşenler içermektedir (Chan ve ark., 2007). Çeşitli hastalıklara karşı koruyucu etkisinin iyi bir antioksidan olmasından kaynaklandığı düşünülmektedir (Pietta ve ark., 2000). Klinik çalışmalar, dolaşım zayıflığı, kalp hastalığı, göz hastalığı, kulak çınlaması, kronik beyin hastalıkları, kısa süreli hafıza kaybı, beyin travması, depresyon, demans ve yaşlılıkla ilişkili durumların tedavisinde standardize ginkgo ekstraktı kullanılabileceğini göstermektedir. Ginkgo'nun birincil klinik uygulaması, beyin yetmezliği gibi periferik damar hastalığının tedavisinde olmuştur. Ginkgo yaprağı ekstresi hafizanın iyileştirilmesinde ve multipl sklerozun tedavisinde etkilidir. Ayrıca Alzheimer hastalığının ve diğer demans tiplerinin önlenmesi ve tedavisinde yardımcı olabilir (Pohl ve Lin, 2018; Walkoviak ve ark., 2019; Shu ve ark., 2019).

Ginkgo biloba bitkisinin "EGb761" olarak kodlanan standardize ekstresi birçok ülkede bitkisel ilaç olarak en sık kullanılan ürünlerden biridir (Yang ve ark., 2002). Günümüzde kullanılan standart GBE içinde flavon glikozitler, terpenoidler ve çeşitli organik asitler bulunur. Flavon glikozitler; kuarsetin, kamferol ve izohamnetin bileşiklerinden oluşur. Bunların güçlü antioksidan özellikleri vardır. Ortamda bulunan hidroksil, peroksil ve süperoksit radikalleri gibi serbest radikalleri sönümleyerek hücreleri protein ve lipid gibi biyolojik makromoleküllerin oksidasyonuna karşı korurlar (Goh ve Barlow, 2002; Güleç ve ark., 2004).

Bitkinin ana bileşenleri; flavonoidler, proantosiyaninler, trilaktonik diterpenler (ginkgolid A, B ve C) ve seskiterpen bilabolidlerdir. Ginkgo biloba'nın sağlık üzerindeki etkilerinin içerdiği polifoneller, flavonoidler ve ginkgolitlerden kaynaklandığı düşünülmektedir. Ginkgolit metabolizmada trombosit aktive edici faktörü inhibe ederken, yapısındaki antioksidan maddeler ortamda bulunan hidroksil, süperoksit ve peroksil radikalleri gibi serbest radikalleri sönümleyerek hücreleri protein ve lipid oksidasyonuna karşı korurlar. Bu nedenle, Ginkgo biloba yaprak özleri pek çok ülkede reçeteli bitkisel ilaçlar olarak kullanılmaktadır (DeFeudis ve Drieu, 2000; Omidkhoda ve ark., 2019).

Fenolik maddeler, meyve, sebze, baharat, kahve, çay ve şarap gibi bitkisel kaynaklı yiyecek ve içecekler ile insan vücuduna girerler. Tüm bitki dokularında bulunurlar, bulundukları dokuya göre miktarları ve türleri değişebilir (Moco ve ark., 2007; Viskupicova ve ark., 2008). Fenolik maddelerin ekstraksiyonu ve analizi konusunda literatürde pek çok yöntem tanımlanmıştır. Ekstraksiyon için genellikle su, metanol, etanol, aseton veya bunların karıştırılmasıyla hazırlanan çözücüler kullanılır. Bağlı fenolik maddeler, asidik, bazik veya hem asidik hem bazik ortamda hidroliz edilerek ekstrakte edilir. (Mattila ve Kumpulainen, 2002; Shadidi ve Yeo, 2016). Son yıllarda, hedef bileşiklerin farklı materyallerden ekstraksiyonu için yeni ekstraksiyon teknikleri geliştirilmiştir. Bunlardan biri olan ultrasonik ekstraksiyon, geleneksel ektraksiyon yöntemleri yerine meyveler, yapraklar, saplar, ve bitki tohumları gibi bitkilerin farklı kısımlarından fenolik bileşiklerin ekstraksiyonunda yaygın olarak kullanılmaktadır. Ultrasonik ekstraksiyon çalışmaları ekstraksiyon veriminde $\% 6$ ile \%35 arasında iyileşmeler olduğunu ayrıca diğer ekstraksiyon yöntemlerinden daha hızlı bir yöntem olduğunu göstermiştir (Aybastıer ve ark., 2013; Dent ve ark., 2015).

Dünyada en çok satılan bitkiler arasında yer alan Ginkgo biloba, ülkemizde ilaç, gıda takviyesi ve kuru yaprak olmak üzere 3 farklı şekilde satışa sunulmaktadır. Yapılan çalışmada bu 3 farklı ürünün ultrasonik ekstraksiyonu gerçekleştirilmiştir. Ekstraktların Folin-Ciocalteu yöntemi ile toplam fenolik madde, ABTS yöntemi ile antioksidan kapasite, HPLC ile de içerdiği fenolik maddelerin kantitatif tayini yapılmıştır. En yüksek antioksidan özelliklere sahip olan ürünün reçeteli ilaç olarak satılan form olduğu tespit edilmiştir. HPLC analizleri sonucu yapıdaki temel fenolik maddenin rutin olduğu belirlenmiştir.

\section{Materyal ve Metot}

\subsection{Materyal}

Ginkgo biloba kuru yaprağı ve tablet formunda gıda takviyesi aktardan temin edilmiştir. Tablet formunda ilaç olarak satılan Ginkgo biloba yaprakları kuru ekstresi eczaneden temin edilmiştir. Asetonitril, formik asit, $\mathrm{HCl}$ ve metanol Merck’ten (Darmstadt, Almanya) satın alınmıştır. Etanol, ABTS (2,2'-azino-bis(3-etilbenztiazolin-6-sülfonik asit)), Folin-Ciocalteu reaktifi, gallik asit, $( \pm)-6$ hidroksi-2,5,7,8-tetrametilkroman-2-karboksilik asit (troloks), protokatekuik asit, $p$-hidroksi benzoik asit, rutin, kamferol, kamferol-3glikozit ve kuersetin Sigma-Aldrich’ten (St. Louis, MO., ABD) satın alınmıştır. Tüm deneysel işlemlerde analitik saflıkta kimyasallar ve ultra saf su kullanılmıştır.

\subsection{Ultrasonik ekstraksiyon}

İlaç, Ginkgo biloba yaprağı ve gıda takviyesi ürünlerin her biri ayrı cam viale alınarak üzerine $\% 60$ metanol çözeltisi ilave edilmiştir. Aynı işlem asidik ekstraksiyon için $2 \mathrm{M} \mathrm{HCl}$ içeren \%60 metanol çözeltisi ilave edilerek de yapılmıştır. Cam vialler, ultrasonik banyoya yerleştirilerek $50^{\circ} \mathrm{C}^{\prime} \mathrm{de} 100 \mathrm{dk}$ süre ile $40 \mathrm{kHz}$ ultrasonik ekstraksiyon gerçekleştirilmiştir. Ekstraksiyon sonunda süzgeç kâğıdından süzülen ekstraktlar $+4{ }^{\circ} \mathrm{C}$ 'de muhafaza edilmiştir. 


\subsection{Toplam Fenolik Madde Tayini}

Toplam fenolik madde tayini Folin-Ciocalteu yöntemi kullanılarak yapılmıştır (Aybastıer ve ark., 2013). 0,1 M NaOH içinde \%2'lik $\mathrm{Na}_{2} \mathrm{CO}_{3}$ olacak şekilde Lowry A çözeltisi ve \%1'lik $\mathrm{NaKC}_{4} \mathrm{H}_{4} \mathrm{O}_{6}$ içinde $\% 0,5 \mathrm{CuSO}_{4}$ olacak şekilde Lowry B çözeltisi hazırlanmıştır. Lowry A ve Lowry B 50:1 (v/v) oranında karıştırılarak Lowry C çözeltisi hazırlanmıştır. Analiz tüplerine 0,1 mL örnek/standart ve $1,9 \mathrm{~mL}$ saf su, $2,5 \mathrm{~mL}$ Lowry C çözeltisi ve 0,25 mL Folin-Ciocalteu reaktifi eklenerek, $30 \mathrm{dk}$ karanlıkta bekletilmiştir. Süre sonunda $750 \mathrm{~nm}$ 'de absorbansı ölçülmüştür. Toplam fenolik madde tayininde standart madde olarak gallik asit kullanılmıştır. Kalibrasyon grafiği oluşturmak için farklı konsantrasyonlardaki gallik asit çözeltileri hazırlanmıştır. Standartların konsantrasyonuna karşılık absorbans grafiği çizilerek, en küçük kareler yöntemiyle doğru denklemi belirlenmiştir. Numuneler için toplam fenolik madde miktarları elde edilen kalibrasyon denklemi kullanılarak mg gallik asit/g örnek şeklinde hesaplanmıştır.

\subsection{Antioksidan Kapasite Tayini}

Antioksidan kapasite tayini ABTS yöntemi kullanılarak yapılmıştır (Aybastıer ve ark., 2013). Etanol içinde 6 mM ABTS stok çözeltisi hazırlanarak, analizler için 1:10 oranında saf su ile seyreltilerek kullanılmıştır. Analiz için 0,1 mL örnek/standart üzerine 3,9 mL etanol ve seyreltilmiş ABTS çözeltisinden $1 \mathrm{~mL}$ eklenerek $6 \mathrm{dk}$ beklenip, 734 nm'de absorbansı ölçülmüştür. Antioksidan madde içermeyen kör örneğin absorbansına göre her bir numunenin \% inhibisyon değeri hesaplanmıştır. Antioksidan kapasite tayininde standart madde olarak troloks kullanılmıştır. Kalibrasyon grafiği oluşturmak için farklı konsantrasyonlarda troloks çözeltileri hazırlanmıştır. Troloks miktarına karşılık \% inhibisyon grafiği çizilerek, en küçük kareler yöntemiyle doğru denklemi belirlenmiştir. Numuneler için antioksidan kapasite miktarları edilen kalibrasyon denklemi kullanılarak mg troloks/g örnek şeklinde hesaplanmıştır.

\subsection{HPLC Analizi}

Agilent 1200 HPLC sistemi ve XBridge $(4,6$ x $250 \mathrm{~mm}, 3,5 \mu \mathrm{m})$ kolon kullanılarak analizler gerçekleştirilmiştir. Fenolik bileşiklerin HPLC ile analizi için $10 \mu \mathrm{L}$ enjeksiyon hacmi ve $0,5 \mathrm{~mL} / \mathrm{dk}$ akış hızı ile çalışılmıştır. Hareketli faz olarak formik asitin sudaki \%1'lik (h/h) çözeltisi (çözücü A) ve asetonitril (çözücü B) kullanılmıştır. 0-10 dk \%13 B, 10-20 dk \%41,5 B, 20-25 dk \%70 B, $25-35 \mathrm{dk} \% 10 \mathrm{~B}$ şeklinde gradient program uygulanmıştır. Toplam analiz süresi $35 \mathrm{dk}$ ve kolon sıcaklığ $25^{\circ} \mathrm{C}$ 'dir. $280 \mathrm{~nm}$ dalga boyunda protokatekuik asit, $p$-hidroksi benzoik asit, $360 \mathrm{~nm}$ dalga boyunda rutin, kamferol, kamferol-3-glikozit, kuersetin tayin edilmiştir. Her bir maddenin miktarı, farklı konsantrasyonlarda çözeltiler kullanılarak en küçük kareler yöntemiyle elde edilen kalibrasyon denklemi yardımıyla mg/g örnek şeklinde hesaplanmıştır.

\section{Araştırma Sonuçları ve Tartışma}

\subsection{Toplam Fenolik Madde ve Antioksidan Kapasite}

Farklı formlardaki Ginkgo biloba ekstrasyonları, daha etkin bir ekstraksiyon gerçekleşmesi için ultrasonik ekstraksiyon yöntemiyle gerçekleştirilmiştir. Yüksek sıcaklıkta antioksidan maddeler termal bozunmaya uğrayabileceğinden, düşük sıcaklıklarda da ekstraksiyon verimi düşebileceğinden ekstraksiyon sıcaklığ $150{ }^{\circ} \mathrm{C}$ olarak belirlenmiştir (Şahin ve ark., 2013). Glikozit yapıdaki antioksidan maddeleri hidroliz ederek aglikonlarına dönüştürerek de analiz etmek amacıyla her bir numune için hem asitli hem de asitsiz ortamda ekstraksiyon gerçekleştirilmiştir. Folin-Ciocalteu yöntemiyle belirlenen toplam fenolik madde miktarları ve ABTS yöntemiyle belirlenen antioksidan kapasite miktarları Tablo 1'de verilmiştir.

Tablo 1. Farklı formlardaki Ginkgo biloba'nın toplam fenolik madde ve antioksidan kapasite değerleri

\begin{tabular}{lrr}
\hline & $\begin{array}{r}\text { Toplam Fenolik Madde } \\
\text { (mg gallik asit/g örnek) }\end{array}$ & $\begin{array}{r}\text { Antioksidan Kapasite } \\
\text { (mg troloks/g örnek) }\end{array}$ \\
\hline İlaç & $68,16 \pm 1,83$ & $59,75 \pm 3,57$ \\
İlaç asidik ortam & $80,27 \pm 6,55$ & $56,48 \pm 8,66$ \\
Gıda takviyesi & $19,00 \pm 0,32$ & $15,88 \pm 0,43$ \\
Gıda takviyesi asidik ortam & $20,24 \pm 0,21$ & $15,43 \pm 1,66$ \\
Yaprak & $22,18 \pm 0,03$ & $41,06 \pm 1,88$ \\
Yaprak asidik ortam & $19,44 \pm 3,12$ & $32,61 \pm 1,80$ \\
\hline
\end{tabular}

En yüksek toplam fenolik madde ve antioksidan kapasite değerlerine ilaç olarak satılan standart Ginkgo biloba ekstresinin sahip olduğu belirlenmiştir. Gıda takviyesi ürünün toplam fenolik madde miktarı yaprağın toplam fenolik miktarına yakınken, antioksidan kapasite değeri yapraktan daha düşük bulunmuştur. Bunun nedeni gıda takviyesi olarak satılan ürünün içine katılmış olabilecek yardımcı maddeler olabilir. Eklenen yardımcı maddeler toplam fenolik madde analizine girişim yaparak değerin artmasına yol açarken, antioksidan kapasite analizine girişim yapmadığından değerlerin düşük kalmasına yol açmış olabilir. Yaygın olarak kullanılan şeker yapısındaki yardımcı maddelerin toplam fenolik madde tayinine girişim yaptığı bilinmektedir (Singleton ve ark., 1999).

Asidik ortamdaki ekstraksiyon ile asit katılmadan yapılan ekstraksiyon sonuçları arasındaki farklar Ginkgo biloba'nın yapısında bulunan hidroliz olabilen bileşiklerden kaynaklanmaktadır. Glikozit yapıdaki bir bileşik ile asidik hidroliz sonucu oluşan aglikonu farklı güçte antioksidan özelliğe sahip olabilirler (Xiao, 2017). 


\subsection{Antioksidan Madde İçeriği}

Ekstraktların spektrofotometrik analizleri yapıldıktan sonra içerdikleri antioksidan maddelerin belirlenmesi için HPLC analizleri gerçekleştirilmiştir. Kantitatif tayin yapabilmek için öncelikle antioksidan maddelerin yüksek saflıktaki standartları kullanılarak her biri için kalibrasyon grafiği oluşturulmuştur. Antioksidan maddelere ait kalibrasyon verileri Tablo 2'de görülmektedir.

Tablo 2. Antioksidan maddeler için HPLC'de hazırlanan kalibrasyon verileri

\begin{tabular}{lccccc}
\hline & $\begin{array}{c}\text { Dalgaboyu } \\
(\mathrm{nm})\end{array}$ & $\begin{array}{c}\text { Alıkonma } \\
\text { zamanı } \\
(\mathrm{dk})\end{array}$ & Kalibrasyon denklemi & $\begin{array}{c}\text { Regresyon } \\
\text { katsayısı } \\
\left(\mathrm{R}^{2}\right)\end{array}$ & $\begin{array}{c}\text { Derişim } \\
\text { aralığ } \\
(\mathrm{mg} / \mathrm{L})\end{array}$ \\
\hline Protokatekuik asit & 280 & 11,60 & $\mathrm{y}=26,5501 \mathrm{x}-13,8184$ & 0,9915 & $10-300$ \\
$p$-hidroksi benzoik asit & 280 & 17,63 & $\mathrm{y}=30,0120 \mathrm{x}+8,8352$ & 0,9891 & $10-200$ \\
Rutin & 360 & 22,29 & $\mathrm{y}=14,6890 \mathrm{x}-2,3944$ & 0,9902 & $10-500$ \\
Kamferol-3-glikozit & 360 & 23,94 & $\mathrm{y}=78,2360 \mathrm{x}+18,1260$ & 0,9928 & $10-100$ \\
Kuersetin & 360 & 27,92 & $\mathrm{y}=97,9530 \mathrm{x}+6,7120$ & 0,9932 & $10-100$ \\
Kamferol & 360 & 29,41 & $\mathrm{y}=81,2450 \mathrm{x}+16,4350$ & 0,9887 & $10-100$ \\
\hline
\end{tabular}

Her bir ekstrakt için yapılan HPLC analizi sonucu elde edilen kromatogramlardaki piklerin alıkonma zamanı ve spektrumu kontrol edilerek hangi antioksidan maddeye ait olduğu tespit edilmiştir. Şekil 1'de ilaç formundan hazırlan ekstrakta ait HPLC kromatogramı verilmiştir. Pik alanı değerleri ilgili kalibrasyon grafiğinde yerine koyularak kantitatif analiz gerçekleştirilmiştir. Elde edilen sonuçlar Tablo 3'de görülmektedir.

(a)

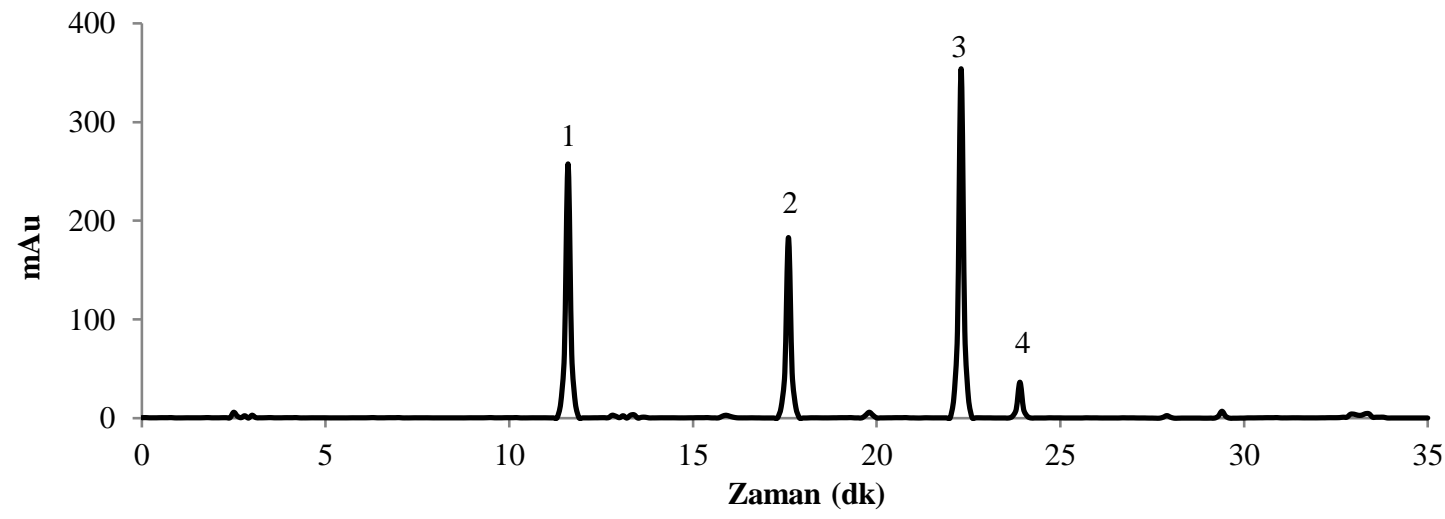

(b)

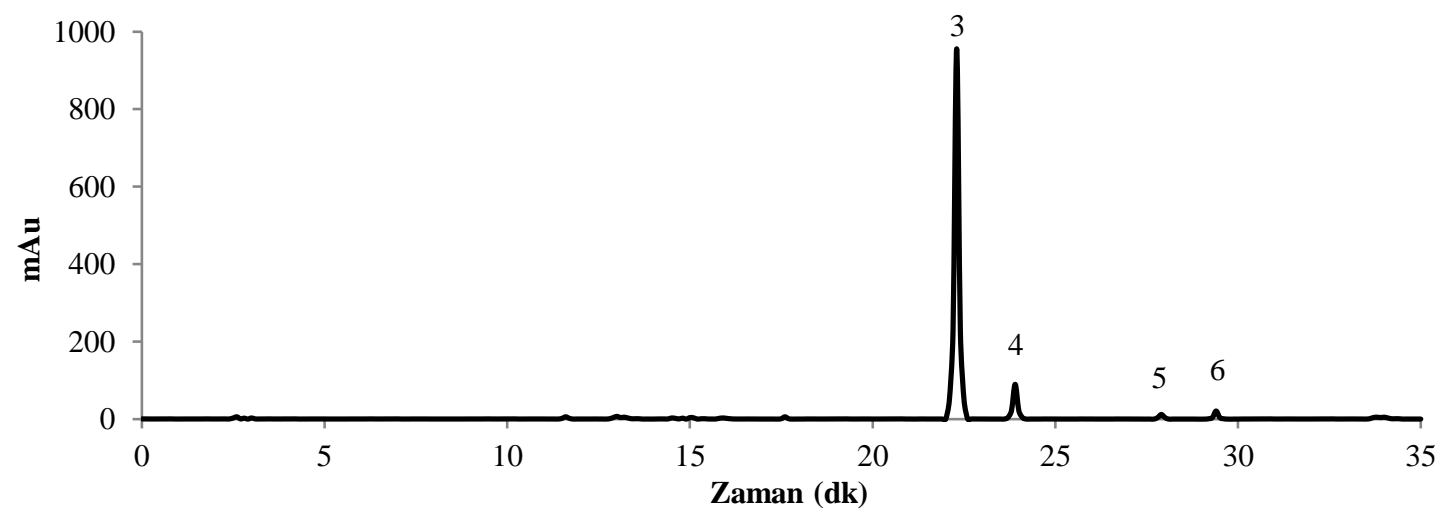

Şekil 1. Ilaç formundaki Ginkgo biloba'nın asitsiz ekstraktının (a) $280 \mathrm{~nm}$ ve (b) $360 \mathrm{~nm}$ 'deki HPLC kromatogramları (1:Protokatekuik asit, 2:p-hidroksi benzoik asit, 3:Rutin, 4:Kamferol-3-glikozit, 5:Kuersetin, 6:Kamferol) 
Avrupa Bilim ve Teknoloji Dergisi

Tablo 3. Farklı formlardaki Ginkgo biloba'nın içerdiği antioksidan madde miktarları (mg/g)

\begin{tabular}{lrccccr}
\hline & \multicolumn{1}{c}{ A1 } & A2 & B1 & B2 & C1 & C2 \\
\hline Protokatekuik asit & $3,22 \pm 0,36$ & $2,67 \pm 0,13$ & $0,08 \pm 0,01$ & $0,05 \pm 0,01$ & $0,17 \pm 0,01$ & $0,10 \pm 0,01$ \\
$p$-hidroksibenzoik asit & $2,28 \pm 0,11$ & $0,70 \pm 0,04$ & $0,06 \pm 0,01$ & - & - & - \\
Rutin & $11,95 \pm 0,75$ & $7,72 \pm 0,38$ & $8,75 \pm 0,06$ & $6,92 \pm 0,34$ & $0,65 \pm 0,02$ & $0,36 \pm 0,03$ \\
Kamferol-3-glikozit & $1,11 \pm 0,09$ & $1,48 \pm 0,11$ & $0,03 \pm 0,00$ & $0,06 \pm 0,01$ & $0,05 \pm 0,01$ & $0,05 \pm 0,01$ \\
Kuersetin & $0,08 \pm 0,01$ & $1,47 \pm 0,19$ & $0,08 \pm 0,01$ & $0,53 \pm 0,04$ & - & $0,02 \pm 0,00$ \\
Kamferol & $0,16 \pm 0,02$ & $1,35 \pm 0,05$ & $0,03 \pm 0,00$ & $0,04 \pm 0,01$ & $0,07 \pm 0,01$ & $0,10 \pm 0,01$ \\
\hline
\end{tabular}

$\begin{array}{ll}\text { A1: İlaç } & \text { A2: İlaç asidik ortam } \\ \text { B1: G1da takviyesi } & \text { B2: G1da takviyesi asidik ortam } \\ \text { C1: Yaprak } & \text { C2: Yaprak asidik ortam }\end{array}$

Analiz edilen tüm ekstraktlarda bir flavonoid glikozit olan rutin (kuersetin-3-rutinosit) temel fenolik madde olarak belirlenmiştir. Rutinin ve kuersetinin moleküler yapıları Şekil 2'de görülmektedir. Rutin, bir flavonoid olan kuersetinin 3. karbon atomuna bağlı $\mathrm{OH}$ grubuna rutinozun eklenmesiyle oluşur. Tüm numunelerde asidik ekstraksiyon yapıldığında rutin miktarının azaldığı, kuersetin miktarının ise arttığı görülmektedir. Yaprağın asidik ekstraksiyonunda $0,02 \mathrm{mg} / \mathrm{g}$ kuersetin belirlenirken, asitsiz ekstraksiyonunda kuersetin tespit edilememiştir. Bunların nedeni, asidik ortamda rutinin asidik hidrolize uğraması sonucu kuersetinin ortaya çıkmasıdır (Boyle ve ark., 2000; Li ve ark., 2016).

Bir flavonoid olan kamferol ve onun glikoziti olan kamferol-3-glikozit de Ginkgo biloba'nın içeriğinde bulunmaktadır. Kamferol ile kamferol-3-glikozitin kimyasal yapıları ve etkileri kuersetin ile rutine benzemektedir. Son yıllarda yapılan çalışmalar flavonoidlerin antioksidan özelliklerinin yanında antiinflamatuvar, antikanser, antiviral, antiallerjik, antitrombotik ve damar genişletici gibi özelliklerinin de bulunduğunu göstermektedir (Montano ve ark., 2011; Wang ve ark., 2018).

(a)

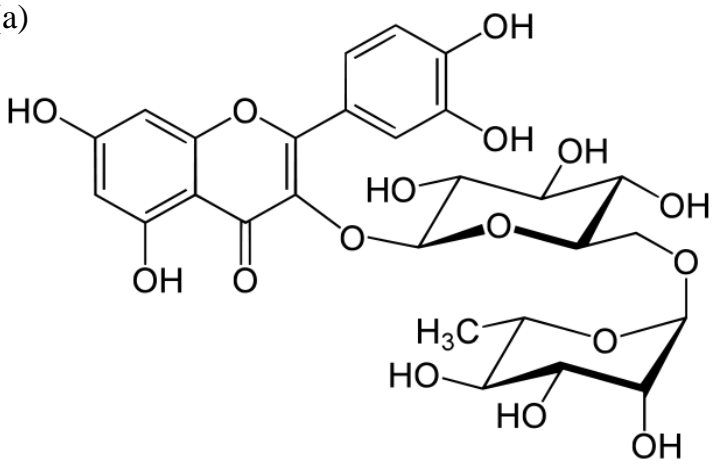

(b)<smiles>O=c1c(O)c(-c2ccc(O)c(O)c2)oc2cc(O)cc(O)c12</smiles>

Şekil 2. Rutin (a) ve kuersetinin (b) moleküler yapıları

Protokatekuik asit ve $p$-hidroksibenzoik asit, hidroksibenzoik asitler grubunda yer alan fenolik asitlerdir. $p$-hidroksi benzoik asit gıda takviyesi ürünün asidik ekstraksiyonu ve yaprağın asitli-asitsiz ekstraksiyonlarında gözlenememiştir. Bu fenolik asitler pek çok bitkinin yapısında bulunurlar. Suda çözünürlükleri flavonoidlere göre daha iyidir. Fenolik asitler son yıllarda özellikle kanser ve koroner kalp hastalıkları gibi ölümcül hastalıklara karşı koruyucu etkide bulunma potansiyelleri nedeniyle üzerinde oldukça yaygın çalışmalar yapılan bileşiklerdir. Bununla birlikte antiinflamatuvar, antimikrobiyal, antioksidan, anti-trombotik ve damar genişletici gibi pek çok etkisi olduğu kanıtlanmış ve bu yararlı etkilerinin temel sebebinin antioksidan özellik göstermeleri olduğu rapor edilmiştir (Balasundram ve ark., 2006; Tanase ver ark., 2019).

Farklı formlardaki Ginkgo biloba ürünlerinin içerdikleri antioksidan madde miktarları açısından oldukça farklı oldukları belirlenmiştir. Bunun nedenlerinden biri hazırlanmalarında farklı kaynaklardan gelen, farklı yerlerde yetişmiş bitkiler kullanılmasıdır. Bitkilerin içerikleri yetiştikleri bölgeye, aldıkları su, güneş 1şığı ve kimyasal gibi faktörlere göre değişmektedir (Xu ve ark., 2017). Bu farklılığın diğer bir nedeni ise satılan bu ürünlerin hazırlanma aşamaladır. Yaprak, ağaçtan toplanıp, kurutulduktan sonra satılırken, gıda takviyesi ürün çeşitli işlemlere kapsül haline getirilerek satılmaktadır. İlaç olan ürün ise daha sıkı denetimlerle ve dünyanın her yerinde değiştirilmeyen standardize bir hazırlama yöntemi ile içeriği kontrol edilerek hazırlanmaktadır. Bu nedenlerle en güvenilir Ginkgo biloba formunun ilaç olarak satılan tablet form olduğu söylenebilir. 


\section{Sonuç}

Bu çalışmada, sağlık üzerinde olumlu etkileri olduğu düşünüldüğü için yüz yıllardır kullanılan Ginkgo biloba'nın antioksidan özellikleri araştırıldı. Dünyada ve ülkemizde kolaylıkla ulaşılabilen film tablet formunda ilaç, kapsül formunda gıda takviyesi ve kuru yaprak olmak üzere üç farklı formun asidik ve asidik olmayan ortamda ultrasonik ekstraksiyon ile hazırlanan ekstraktları analiz edildi. Ginkgo biloba bitkisinin içerdiği temel antioksidan maddenin rutin olduğu belirlendi. Film tablet formunda ilaç olarak satılan standart Ginkgo biloba ekstresinin, gıda takviyesi ürün ve kuru yaprağa göre oldukça yüksek antioksidan özelliğe sahip olduğu belirlendi. Literatürde de belirtilen bazı yan etkilerin ve kullanılan başka ilaçlarla etkileşimlerin ortaya çıkmaması için, Ginkgo biloba bitkisi hekim tavsiyesi üzerine ve standardize ekstre içeren reçeteli ilaç formunda kullanılmadır. Gıda takviyesi ya da yaprak olarak kullanıldığında içeriği ve dolayısı ile etkileri/yan etkileri değişkenlik gösterebileceğinden dikkatli olunmalıdır.

\section{Kaynakça}

Aybastier Ö, Şahin S, Demir C, 2013. Response Surface Optimized Ultrasonic-Assisted Extraction of Quercetin and Isolation of Phenolic Compounds From Hypericum perforatum L. by Column Chromatography. Separation Science and Technology, 48: $1665-1674$.

Balasundram N, Sundram K, Samman S, 2006. Phenolic compounds in plants and agri-industrial by-products: Antioxidant activity, occurrence, and potential uses. Food Chemistry 99: 191-203.

Boyle SP, Dobson VL, Duthie SJ, Hinselwood DC, Kyle JAM, Collins AR, 2000. Bioavailability and efficiency of rutin as an antioxidant: a human supplementation study. European Journal of Clinical Nutrition, 54: 774-782.

Chan PC, Xia Q, Fu PP, 2007. Ginkgo Biloba Leave Extract: Biological, Medicinal, and Toxicological Effects. Journal of Environmental Science and Health Part C, 25: 211-244.

DeFeudis FV, Drieu K, 2000. Ginkgo Biloba Extract (EGb 761) and CNS Functions: Basic Studies and Clinical Applications. Current Drug Targets, 1: 25-58.

Dent M, Uzelac VD, Garofulic IE, Bosiljkov T, Jezek D, Brncic M, 2015. Comparison of Conventional and Ultrasound-assisted Extraction Techniques on Mass Fraction of Phenolic Compounds from Sage (Salvia officinalis L.). Chemical and Biochemical Engineering Quarterly, 29(3): 475-484.

Goh LM, Barlow PJ, 2002. Antioxidant capacity in Ginkgo biloba. Food Research International, 35: 815-820.

Güleç M, Yılmaz R, Iraz M, Ağlamış S, Söğü S, 2004. Sisplatin Nefrotoksisitesi Oluşturulan Siçanların Plazma Glutatyon Peroksidaz, Süperoksit Dismutaz, Adenozin Deaminaz Aktiviteleri ve Nitrik Oksit Seviyelerine Ginkgo Biloba Ekstraktının Etkileri. Türkiye Klinikleri, 24: 585-591.

Hohmann N, Wolf EM, Rigault P, Zhou W, Kiefer M, Zhao Y, Fu CX, Koch MA, 2018. Ginkgo biloba's footprint of dynamic Pleistocene history dates back only 390,000 years ago. BMC Genomics, 19:299.

Li Y, Yao J, Han C, Yang J, Chaudhry MT, Wang S, Liu H, Yin Y, 2016. Quercetin, Inflammation and Immunity. Nutrients, 8: 167.

Liu C, Liu S, Zhang L, Wang X, Ma L, 2018. Partition Behavior in Aqueous Two-Phase System and Antioxidant Activity of Flavonoids from Ginkgo biloba. Applied Sciences, 8: 2058.

Mattila P, Kumpulainen J, 2002. Determination of free and total phenolic acids in plant-derived foods by HPLC with diode-array detection. Journal of Agricultural and Food Chemistry 50: 3660-3667.

Moco S, Capanoglu E, Tukinov Y, Bino R, Boyacioglu D, Hall RD, Vervoort J, De Vos R, 2007. Tissue specia-lization at the metabolite level is perceived during the development of tomato fruit. Journal of Experimental Botany, 58: 4131-4146.

Montaño JMC, Burgos-Morón E, Pérez-Guerrero C, López-Lázaro M, 2011. A Review on the Dietary Flavonoid Kaempferol. MiniReviews in Medicinal Chemistry, 11, 298-344.

Nakanishi K, 2005. Terpene trilactones from Gingko biloba: From ancient times to the 21st century. Bioorganic \& Medicinal Chemistry, 13: 4987-5000.

Omidkhoda SF, Razavi BM, Hosseinzadeh H, 2019. Protective effects of Ginkgo biloba L. against natural toxins, chemical toxicities, and radiation: A comprehensive review. Phytotherapy Research, 33: 2821-2840.

Pietta P, Simonetti P, Gardana C, Mauri P, 2000. Trolox equivalent antioxidant capacity (TEAC) of Ginkgo biloba flavonol and Camellia sinensis catechin metabolites. Journal of Pharmaceutical and Biomedical Analysis, 23: 223-226.

Pohl F, Lin PKT, 2018. The Potential Use of Plant Natural Products and Plant Extracts with Antioxidant Properties for the Prevention/Treatment of Neurodegenerative Diseases: In Vitro, In Vivo and Clinical Trials. Molecules, 23: 3283.

Rouse J, 1998. Ginkgo biloba: Mind, Mood, and Memory. Journal of Applied Nutritional Science, 6 (7):1-2.

Shahidi F, Yeo JD, 2016. Insoluble-Bound Phenolics in Food. Molecules, 21: 1216.

Shu Z, Shar AH, Shahen M, Wang H, Alagawany M, El-Hack MEA, Kalhoro SA, Rashid M, Shar PA, 2019. Pharmacological Uses of Ginkgo biloba Extracts for Cardiovascular Disease and Coronary Heart Diseases. International Journal of Pharmacology, 15: 1-9.

Singleton VL, Orthofer R, Lamuela-Raventos RM, 1999. Analysis of total phenols and other oxidation substrates and antioxidants by means of Folin-Ciocalteu reagent. Methods in Enzymology, 299: 152-178.

Şahin S, Aybastıer Ö, Işık E, 2013. Optimisation of ultrasonic-assisted extraction of antioxidant compounds from Artemisia absinthium using response surface methodology. Food Chemistry, 141: 1361-1368.

Tanase C, Cosarca S, Muntean DL, 2019. A Critical Review of Phenolic Compounds Extracted from the Bark of Woody Vascular Plants and Their Potential Biological Activity. Molecules, 24: 1182.

Viskupicova J, Ondrejovic M, Sturdik E, 2008. Bioavailability and metabolism of flavonoids. Journal of Food Nutrition and Research 47(4): 151-162 
Walkowiak A, Ledziński L, Zapadka M, Kupcewicz B, 2019. Detection of adulterants in dietary supplements with Ginkgo biloba extract by attenuated total reflectance Fourier transform infrared spectroscopy and multivariate methods PLS-DA and PCA. Spectrochimica Acta Part A: Molecular and Biomolecular Spectroscopy, 208: 222-228

Wang J, Fang X, Ge L, Cao F, Zhao L, Wang Z, Xiao W, 2018. Antitumor, antioxidant and anti-inflammatory activities of kaempferol and its corresponding glycosides and the enzymatic preparation of kaempferol. Plos One, 13(5): e0197563.

Xiao J, 2017. Dietary flavonoid aglycones and their glycosides: Which show betterbiological significance? Critical Reviews in Food Science and Nutrition, 57(9): 1874-1905.

Xu DP, Li Y, Meng X, Zhou T, Zhou Y, Zheng J, Zhang JJ, Li HB, 2017. Natural Antioxidants in Foods and Medicinal Plants: Extraction, Assessment and Resources. International Journal of Molecular Sciences, 18(96).

Yang C, Xu YR, Yao WX, 2002. Extraction of Pharmaceutical Components from Ginkgo biloba Leaves Using Supercritical Carbon Dioxide. Journal of Agricultural and Food Chemistry, 50: 846-849. 